\title{
Veteran Views of the Library A Qualitative Study
}

As a user population of libraries, veterans have been a much discussed topic for the past several years. Most of the literature has focused on outreach efforts but included very little input from veterans themselves. As part of a larger project to capture veteran narratives of service, and using the Library of Congress Veteran's History Project protocol, veterans were asked about library use and reading habits while in the service. This study sought out feedback from veterans on how they view the library, how they use the library, and what improvements or changes they would like to see in the libraries that they visit. This small study revealed several trends in how veterans viewed themselves, including being self-sacrificing for the good of the whole, being reserved about veteran status, and having a strong sense of community. The trends observed in this small sample can be used to better focus outreach efforts towards this special-needs population.

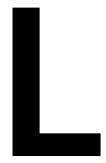

ike many small special populations who use libraries, much of what has generally been written about veterans and libraries discusses veterans without necessarily asking for their input about the services they need. The focus on veterans has been growing over the last ten years in part because of the continuing conflicts in Iraq and Afghanistan and in part because there are roughly 20 million veterans across time periods of peace and war in the United States, who account for roughly 10 percent of the population. ${ }^{1}$ Legislation like the GI Bill has helped veterans come back from service and resume their lives as civilians by assisting them with getting an education. Like the general population, veterans use public, academic, and special libraries. This study asks veterans about their reading habits in the service, their use of the library both in and out of the service, and their recommendations about how libraries can better serve them.

\section{LITERATURE REVIEW}

There is a small but growing body of literature about veterans' library use. Most of the literature centers on outreach to this population. The case study is a popular form. For example, Hoppefield et al. discuss librarian involvement in an entrepreneurial bootcamp for veterans and how that involvement created new relationships and opportunities for both groups. ${ }^{2}$ Another example is the dynamic outreach that Samson engaged in with student veterans at the University of Montana in Missoula where she worked

\section{JJ Pionke}

JJ Pionke (pionke@illinois.edu) is Assistant Professor and Applied Health Sciences Librarian, University Library, University of Illinois at Urbana. He researches and writes in the areas of disability services and services for veterans. 


\section{FEATURE}

with multiple campus groups to develop a robust outreach program. ${ }^{3}$ In broader terms, articles that focus on how to reach out to veterans have been popular and appear both as research and as professional reading for librarians. In the research literature, Phelps gives a detailed analysis on outreach in an academic library and the things to keep in mind when doing so, like how combat experience affects student veterans situational awareness. ${ }^{4}$ In librarian professional literature, specifically CERL News, Sojdehei gives tips on how and where to reach out to student veterans, and Evans created a resource listing for veterans and active duty personnel. ${ }^{5}$

There have also been several articles that focus on the larger picture of what libraries are doing for veterans as well as what they should be doing. Atwood et al.'s article details how the state of Ohio's academic libraries are serving veterans through a discussion of the experiences of each of the article's authors as they highlight their individual outreach projects towards veterans. ${ }^{6}$ Roy et al. took a broader view by examining outreach efforts towards veterans through searching the websites of public libraries state by state throughout the United States. ${ }^{7}$ The researchers then listed each individual outreach initiative. However, they included little analysis of trends and what those trends in outreach towards veterans could indicate. This is a major flaw in their article because it leaves the reader only with a list of outreach initiatives.

LeMire's article, "Supporting Our Troops: Library Services and Support for Veterans," is unusual because she not only examines current trends in library outreach but also includes the veterans who are library employees in her discussion of how veterans themselves are included or excluded in library outreach efforts. ${ }^{8}$ LeMire wisely used her status as a veteran as an entrée into the population.

Mills, Paladino, and Klentzin surveyed and interviewed student veterans at a small private university in Pennsylvania and found that student veterans have nontraditional student hallmarks and that the same strategies that work with nontraditional students should also work with veterans. These include treating veteran students as adults, having a liaison or specialist to conduct outreach to veterans, making the library veteran friendly by creating guides aimed specifically at them, and by updating accessibility for people with disabilities, which many veterans have. ${ }^{9}$

Some research has been done on veteran leisure activities. Only one research study, dating from 1949, asked veterans about their reading habits. About five hundred veterans, all male and all enrolled in college, answered the survey, and the researchers found that "all but four read newspapers regularly-though news items rate second to sports. . . Novels read by most of the five hundred veterans for recreational purposes were the same type as those read during the war years: books easily accessible in inexpensive editions, best sellers available through book clubs-realism as well as romantic escape literature."10 Keeping in mind that this study surveyed veterans from World War II, the results indicate that veterans largely enjoy reading and did so in both the service and in civilian life. More importantly, their reading habits didn't change much whether they were on active duty or discharged. Reading has been especially important in the past for veterans who have been wounded. A follow up study of similar size and scope in the modern era has not been conducted and represents a major gap in the literature.

Wars, and the veterans who survive them, often bring about tremendous changes to technology and society. For example, Rubery, in his discussion of the development of the Talking Book Library after World War I in Great Britain, notes that "blinded servicemen returning from the War gave a degree of urgency to problems of literacy [for the visually impaired] that had long been tolerated. Before the War, blindness had been regrettable and unfortunate, but it was not a problem for which the public bore any direct responsibility. The War changed all that. The British public owed a debt to the disabled ex-servicemen who had sacrificed their eyesight defending the country."11 Because mustard gas and chlorine gas were used fairly extensively in World War I, the incidence of temporary or permanent eye injuries was higher than in previous wars. Rubery also notes that unlike today, veterans with disabilities relied on the public to assist them with rehabilitation and recovery. Today's veterans have many resources from which to draw on when they return to civilian life. However, the amount of resources that are available can be overwhelming, especially in relation to what their needs may be based on what kinds of disabilities they are experiencing.

Veteran's leisure activities have been studied a fair amount within the field of leisure studies, especially as it relates to their reintegration into society and their rehabilitation and recovery from combat experiences. For instance, Chandler et al. examine how leisure experiences can help married couples reintegrate as a couple once the soldier half of the couple returns from deployment. ${ }^{12}$ The issue of leisure experiences and military families is also studied, in part as a way to ameliorate the impacts of military life on families. Melton, Townsend, and Hodge propose how the Creation of Family Experiences framework can be used to develop best practices and favorable outcomes for military families..$^{13}$

Another important area of research is how leisure activities impact veterans in terms of rehabilitation and recovery, including social and mental rehabilitation. In particular, Warren D. Price, in a journal article derived from his master's thesis, explores his own use of leisure through the lens of autoethnography as he recovers from his time in Iraq as a medic. He describes how leisure helped him soothe the worst of his PTSD symptoms, get closer to his family, and ultimately guide him towards a postmilitary career. ${ }^{14}$ Research into the topic of not just leisure experiences of veterans but of how veterans use libraries is limited. The study discussed in this article aimed to directly ask veterans what their reading and library usage experiences were like during their service as well as how they use their local libraries, broadly defined, and what recommendations they would make to libraries. 


\section{METHODOLOGY}

This research was conducted as a subset of a larger oral history project with veterans. We worked with the veteran center on campus and local veteran groups to help recruit participants. The larger project aimed to gather veteran narratives for both deposit in the Library of Congress's Veterans History Project and at the state library, as well as for an exhibit called "Stories of Service" in November 2017.

A short question set (see appendix A) was added to the Library of Congress questions (see appendix B), and the Library of Congress protocol was followed when interviewing veterans. The additional questions focused on reading habits in and out of the service as well as how veterans did or did not use their local libraries. The term local libraries was deliberately left open to interpretation to mean either academic libraries, public libraries, or special libraries, such as the ones found in Veterans Administration hospitals. During the interviews, a graduate student assistant was available to manage paperwork as well as to run the voice recorder. Later, they did focused transcription of the questions related to libraries and reading.

Interviews were conducted in various buildings on campus, although most of the interviews took place in multiple meetings rooms in the main library. Interviews were semistructured. Although there was a question list, questions were omitted if they were not relevant: for example, questions about being drafted were omitted for interviewees that volunteered for service. Based on responses to the question list, each interviewee was asked follow up questions based on previous interview responses to elicit richer and more complete responses. Interviews ranged from 30 to 125 minutes.

\section{Participants}

Twenty-four interviews used the question set discussed in this article. Of the twenty-four people interviewed, twenty were men and four were women. Several branches of the service were covered including ten interviewees from the army, four from the navy, four from the marines, four from the air force, and one from the coast guard. Eighteen of the interviewees had enlisted, five were officers, and one was drafted. The interviewees' service ranged from being drafted in the 1950s, through the Vietnam War and into the turbulent 1980s, including Lebanon, and the ongoing conflicts in Iraq and Afghanistan. Experiences, whether in peace or conflict, included but were not limited to combat, combat support, logistics, and transportation.

\section{FINDINGS}

\section{Reading Habits}

Of the twenty-four men and women interviewed, nineteen of them viewed themselves as readers while five of them identified as nonreaders. Of the readers, one naval officer, DP, who served from 1952-1955, stated, "Those days, you automatically had a book in your back pocket, so if you were stuck in a line-officers not often, but sailors all the timeyou read." Of the nonreaders, GA, who was a careerist in the army until he was injured in Iraq, pointed out the physical nature of an infantryman's work and the requisite physical conditioning required and that it didn't leave time for anything else: "I only read what I had to read in the service. I trained a lot. I was really physically fit at that time in my life so I worked out a lot." Time, desire, branch of the service, and occupation within the military all contributed to how much servicemen and women were readers during their time in the service.

Interviewees were asked about what they read for fun while in the service. For the most part, the interviewees read in the following genres: science fiction, western, thriller, mystery, and horror. Officers and career servicemen (defined as men and women who either served the full twenty years before mandatory retirement or who had the intent to serve the full twenty years but were injured or discharged for some other reason) seemed to gravitate more towards history, especially military history, and biography of military leaders and strategists. Everyone else read more widely based on their individual interests.

When asked what book influenced them the most up until the date of the interview, responses again varied widely. However, many classics were listed including Animal Farm (George Orwell), Brothers Karamazov (Fyodor Dostoevsky), Dune (Frank Herbert), Alice in Wonderland (Lewis Carroll), and Crime and Punishment (Fyodor Dostoevsky). A female navy commander, FJ, pointed to Alice in Wonderland as the most influential book of her life because it reflected her life philosophy. She also stated that "the idea of going down the rabbit hole to adventures and it was just something that fascinated me." This theme of adventure and curiosity was echoed by several interviewees when they explained how they chose their favorite. The adventure theme is represented both in the popular fiction that the servicemen and women read, including science fiction, horror, and thriller, and was reflected in book choices like Alice in Wonderland and Into the Wild (Jon Krakauer) and in more literary and academic works like Dune (Frank Herbert), Chrysanthemum and the Sword (Ruth Benedict), and The Hero with a Thousand Faces (Joseph Campbell). In addition to the theme of adventure and academia, many interviewees also referenced religious or philosophical works such as The Bible, Mere Christianity (C. S. Lewis), and God is Not Great (Christopher Hitchens).

Interviewees said that there wasn't much time for leisure activities when on active duty. Unlike civilian life, which is generally an eight-hour work day, military service personnel, especially in the field, might work ten- to fourteen-hour shifts or more depending on the circumstance. For instance, units that are in an active combat zone and are out on patrol or part of a forward operating base may not have any leisure time at all because they are on constant alert. Still, in times 


\section{FEATURE}

of peace or when not near a conflict zone, servicemen and women do have some leisure time. If they like to read, many bases and ships have small libraries, typically made up of materials that have been read and then left for the next person to find. This is reflected in interviewee ML's narrative about libraries and reading aboard submarines:

I'm a voracious reader so I would devour any magazines or newspapers that were available. . . But you didn't find too many volumes of Shakespeare on board. . . . The only library we had the space for on the submarine was for navship manuals on how to fix things-other than what you brought on with you. ... Once you got to know people, you would learn 'you like this, and I like that,' so you would then trade. But the first few months you're there, you're still trying to figure out who's got what. So having things that are valuable to trade and barter with is important.

ML's narrative was reflected in SK's interview. SK was a marine, and most combat marines on active duty will do at least one tour on a ship. SK was on active duty in the 1980s during which the military was largely made up of men. SK reinforced the idea of sharing materials and the ad hoc nature of those materials. "Yeah, there was one library for the ship. The closest comparison that I can think of is a prison library. Lots of kind of donated books or people bought books and said, 'okay, I've read [it], here I'm gonna stick it in the library.' God knows what you would find. So it was a lot of stuff that eighteen- to twenty-two-year-old guys would read, minus the pornography." Naval librarians select materials for every ship that is commissioned. ${ }^{15}$ However, there are no librarians aboard ships, so once the libraries are established, the continued maintenance of the library is up to the ship commander. That is why there is so much bartering and ad hoc librarianship that happens aboard ships. SK's observation that the materials on ship reflected what "eighteen- to twenty-two-year-old guys would read" is therefore entirely accurate.

\section{Library Usage}

When asked about whether interviewees used libraries as veterans, there was often confusion about the question. This confusion was best epitomized by DO, a Vietnam War-era airman, who exclaimed, "As a veteran? What does a veteran got to do with it? Why would you say 'as a veteran'? ... I don't go anywhere with my veteran status in mind." This confusion over veteran status was supported by ML, a former army military police (MP) officer at a military prison: "I just go as a person. I don't even think about being a veteran much anymore unless someone brings it up. I go to the library because it's there." Still, interviewees did their best to answer the question, with nine of them answering yes to the question and fourteen of them answering no. Of the interviewees who answered no, many of them were either nonreaders or preferred to purchase reading materials. FJ, a female navy commander who is also a librarian, responded to the question of whether or not she uses libraries with a bit of humor: "I don't use the local library because I like to buy things and have them on my Kindle. Like a lot of librarians, I'm a book collector. I have a lot of books of my own, in fact, my husband said to me one time, 'You have too many books!' I said, 'You married a librarian-you should know better!" Though FJ's response was humorous and played on librarian stereotypes of book collection, other negative responses to the question were more serious. RS, a former female marine sergeant, stated, "No, I feel like grad school really ruined me of reading." Many veterans take advantage of the GI Bill, which gives them educational benefits for time served in the military. At the moment of the interview, RS was clearly suffering from educational and reading burnout.

Several of the interviewees expanded on their answers. Four interviewees stated that they used libraries as parents, and four stated that they used libraries as citizens. JMN, a woman who had been in the air force, answered the question at length and in a very nuanced fashion:

For me, it's a free resource that is completely untapped by a lot of people, and I think more importantly, as a social worker and also as a veteran, I think that libraries are now more community centers at this point in time. ... What is a library, how does it really serve the community, not just through learning, but through networking, through collaboration, through bettering what you do and how you serve people that live there.

While she initially answered the question from the point of view of her current profession, she also expanded on her response from the point of view as a parent: "so my children, we live and die with the library. We're there all the time. My family and I are bilingual, so for me having Spanish resources is a really important component. To me, using our libraries is a way people might extend themselves into understanding, hopefully, other languages, other religions and expand their world." JMN is clearly a super user of libraries not just for her profession as a social worker but also as a parent and a member of the community in which she lives. While many veterans did not have as nuanced a view as JMN did, most of them generally did have opinions about what changes they would like to see at their libraries.

\section{Suggestions for Library Improvement}

When asked about what improvements veterans would like to see in their libraries, they generally started by saying something similar to "nothing" and then gave a recommendation or two. Many of the recommendations revolved around purchasing more materials about various topics that relate directly or indirectly to veterans including biographies especially of military leadership and strategists, military history, therapy books, books about the veteran experience, 
books about the transition home and becoming a civilian again, and materials about career choices and financial management. They also requested genres that many patrons ask for: cooking, mysteries, and science fiction. In terms of services, they wanted more audiobooks, social workers, easier browsing of materials, and more multimedia options. While most answers were short, several veterans had more substantive responses, especially relating to how libraries could better include or reach veterans. NO, a former coast guard lieutenant who is very active in the veteran community, articulated the needs of this special population in a way that highlights the need for outreach while being sensitive to the experiences that veterans have had and have brought home with them.

To me, this community, with the libraries, is very proveteran, very pro-"how do we promote more visibility about veterans in the community and what should we look at?" Part of this has led to the discussion of how we don't want everything to always go back to trauma. Another veteran commits suicide, another veteran comes back with PTSD. Very important, but not the whole story. I think that libraries are uniquely positioned to bring the community together and bring a deeper awareness of all those layers so that things don't just get stuck and we keep perpetuating stereotype after stereotype.

NO's point about stereotypes is particularly important because the image of the wounded veteran is one that is emphasized by the media constantly, although it is not representative of what most veterans experience. According to McGrath, as of 2005 in Iraq, when civilian contractors who took over noncombat jobs that soldiers had formally fulfilled were included in calculations, 75 percent of the jobs in the army were noncombat roles. ${ }^{16}$ McGrath also states that of the army personnel in combat roles, which is roughly 30 percent of the army, only 11 percent had been designated as combat elements, meaning they had been in combat. ${ }^{17}$ This is significant because the emphasis by the media and by Hollywood is on the wounded and potentially dangerous veteran. NO's articulation of the very real disparity between the lived experiences of the majority of those in the service and what the media, and therefore a great deal of Americans, think veterans experienced during their time in service is an important point to consider for libraries, especially with regard to outreach and programming.

Contrary, and yet complimentary to NO's remarks, is GA, a former army sergeant, who was wounded in combat, who states, "We're not a specialized class. I don't know that they [libraries] need to cater to us. A lot of veterans want to stay under the radar and not have attention drawn to themselves." Most of the veterans that were interviewed expressed this feeling of being part of the general population, rather than a special population. It was echoed by SK, a former marine corporal, who answered the question about changes in the library with "So, here's the thing: just like regular people, no two veterans are alike, no two veterans have the same interests, so the idea of setting up like a veteran's section, I find rude. So it's like you assume because I'm a veteran I want to read a bunch of war histories or something."

While the majority of interviewees expressed an opinion similar to NO and GA, FJ indicated that at least some acknowledgement is welcome but not because they were seeking praise for their service: "I think it would be really useful to have more of that [public acknowledgement of employee service and in this case a former workplace had put up PowerPoint slides with pictures of employees who were veterans on Veteran's Day] going on in libraries because only one percent of the population currently serves. ... I'd like to see libraries promote more of who are people who served and what were their experiences?" Note that her emphasis is more on the experiences that veterans had and not on veteran status. While many veterans never leave the United States, they do leave home and experience different regional cultures, food, and entertainment than they did back home. The culture of the military is that of a total institution much like cloistered monastic orders. Members of the military eat, sleep, learn, work, and play together. The total institution experience of working with people from all over the United States, and being in a place that is different from what the person knows, is what makes servicemen and women unique in many ways. FJ is promoting the idea that those experiences should be shared with others not only as a way to appreciate the person but also as a way to develop a greater sense of community between veterans and nonveterans.

\section{DISCUSSION}

Several general themes emerged from the responses to the questions. This section will examine the major themes and briefly discuss how libraries, both public and academic, might leverage each theme.

\section{Range of Experiences}

A key finding of this study is the range of experiences that veterans have. In this small sample, there were men and women who had been in combat and those who had not. Some were stationed overseas, and some never left the United States. Some served for decades, while others served for a short time. Some were in leadership positions and some were not. The diversity of experiences among the veteran population means that there is no one outreach initiative or "answer" to understand and connect to the veteran community. This diversity is also their greatest strength in part because they all have one thing in common: They were all changed in some way by their experiences. JMN, a former enlisted woman in the air force, captures this feeling of wanting to understand the experience of being in the military. 


\section{FEATURE}

I sit here, even as a veteran, and a very privileged veteran, for me all those little experiences make you the human being you are today-trying to really understand that everyone has a story, everyone has different things they've gone through and some of us have gone through much worse experiences. And I think, too, regardless of how things end up in the end, through all either good or bad experiences you've had, how do you treat another human being? Also, how do you treat yourself and how do you make the best of your situation?

While the need to understand life experiences is present in the civilian population as well, veterans are unique in that they have all had similar experiences with boot camp and living in a total institution. These experiences allow them to relate to one another in ways that civilians typically don't. The need for veterans to understand their experiences, has resulted in a number of coping mechanisms from alcoholism and substance abuse to therapy and support groups. ${ }^{18}$ Libraries can assist veterans in making sense of their experiences in a variety of ways, including offering space for informal coffee conversations between veterans and providing collections of materials that emphasize the return home and transition back into society. Many libraries are already endeavoring to reach out to the veteran community. The article "On the Front Lines: Serving Ohio's Best" breaks down the outreach efforts in academic libraries in Ohio. ${ }^{19}$ These efforts largely involve connecting to, understanding, and assisting veterans not only with their academic endeavors but also at times with navigating the labyrinthine processes of Veterans Administration benefits. The most important way libraries can assist veterans is endeavoring to understand the local community's veterans. Each community's veterans are different with different needs based on a variety of factors, including when and where they served, branch of the military, and whether the veteran was in combat or not. Listening to veterans and what their needs are is tantamount to the success of any outreach efforts to veterans. Supporting veterans in their sense-making is also important and echoed by NO. NO's job focuses on working with veterans. He commented, "I would like to see more programming through libraries to do visibility .... I think that libraries are spaces where communities gather." He goes on to say that many organizations, including libraries, tend to focus on war, death, and trauma, but that those are not the only stories that can or should be told. Specifically, NO would like to see the experiences of veterans highlighted from multiple angles, similar to FJ's comment about highlighting experiences of library employees who are veterans.

\section{Diversity and Intersectionality}

Just as veterans have a broad range of experiences, they also encompass the rich diversity of the United States. People who join the military come from all socioeconomic backgrounds, religions, ethnicities, and sexualities. Acknowledging diversity within the veteran population, not only in terms of military service, but also in terms of how minorities experience their time in the service, is important. While the military does not like to admit its shortcomings, there is a strong history of racism, sexism, misogyny, and sexual violence within the armed services. ${ }^{20}$ Libraries can and should bolster their collections to include materials that discuss these issues both in terms of experiences in the service as well as in terms of recovery. Like most of America, veterans have an intersectional identity. They can be veterans, parents, children, employees, various religions, multiple ethnicities, differing sexualities and genders, and many more. A major finding of this study is that there is no monolithic veteran. Instead, there are individuals who have had experiences in a total institution, potentially including spending time overseas and being in combat zones, who are trying to make sense of the experiences that they had. The intersectionality of veteran identities means that they are not easily defined, understood, or connected to. For libraries, this means that there is no one particular outreach strategy that will work.

While it may seem obvious to say that libraries support and serve people, it is how we support and serve patrons that is important, especially for special needs populations like veterans. Focusing on veteran-lived experiences will be more welcomed than focusing on thanking them for their patriotism. Activities and programs that focus on experiences, like a Human Library event where the public can ask veterans questions about their service in a respectful way, would be one avenue for exploration. However, it is most important to ask the veterans themselves within your community what they want to see in their library. Connecting to veterans and then listening without interrupting is the key to understanding this population.

Listening tips:

- Reach out to local veteran groups including the Veterans of Foreign Wars and the American Legion. Also consider contacting local civic groups like the Lions and the Masons. While not all veterans wish to be involved in community groups, a fair number of them do, and civic groups may be another avenue to connect to veterans.

- Consider the mode of listening-focus groups, coffee conversations, or formal interviews. Adding a question set to an interview project, similar to what was done in the project discussed in this article, is also an easy way to gather more information. Be prepared to create questions in the moment to follow up on veteran responses.

- The length of your discussions will vary wildly from short to long. Prepare for every situation by having extra batteries for recording devices, water for you and the person you are talking to, tissues in the event of tears (there were several incidences of crying during the interviews for the project in this article), and reserve the space that you are talking in for at least two hours even if you only use thirty minutes. 
- Practice self-care, especially if you are doing full Library of Congress Veterans History Project interviews. Most veterans interviewed for this project did not go into graphic detail of the things that they experienced, nonetheless, their experiences will affect you. For instance, in the interviews conducted for this article, one Vietnam War veteran when asked what was a vivid memory of his time in Vietnam responded with, "It was the stench. It was the smell of burning bodies. [he paused for a moment and then said quietly] Next question." Respecting his desire to move on was important and equally important was for the interviewer to later engage in self-care.

\section{Limitations}

This study has several limitations including a lack of ethnic diversity in the interviewees. Several of the interviewees either worked in libraries or had worked in libraries, which may have skewed the results towards readers and fans of libraries. This sample was not representative across all branches of the service nor was it equal between enlisted or officers, volunteer or draftee.

\section{FUTURE RESEARCH}

The findings of this relatively small-scale study indicate that further research is needed, especially a larger scale national survey of veteran patrons on their attitudes about and use of libraries before, during, and after their time in the service. As evidenced earlier, the literature is extremely deficient in research that incorporates veterans' own voices about their needs, desires, and expectations of libraries. A larger and more diverse oral history project with a more defined question set would certainly garner a richer dataset from which to draw understanding of veteran needs. Likewise, there is little to no research about veterans who are library employees and what their needs are from their employers.

\section{CONCLUSION}

Veterans, as a population, are diverse and encompass an intersectional identity. There is no one right way to engage this population because every veteran is different and has had a unique experience during their time in the service. Veteran communities will vary greatly from place to place. Their local libraries, whether public or academic, would benefit from focused inquiry into not only the composition of the local veteran population but also what their needs are. Working with this population, in ways that they need, can be very rewarding as long as libraries are willing to partner with veterans rather than passively minister to them.

\section{ACKNOWLEDGEMENTS}

This study was made possible by the generous support of the University of Illinois at Urbana-Champaign University Library Research and Publication Committee. I would also like to thank Jessica Mason for her tireless and dedicated work on this project. Finally, I would like to thank my interviewees for their patience and willingness to share their stories.

\section{References}

1. Kristen Bialik, "The Changing Face of America's Veteran Population," Pew Research Center, November 10, 2017, accessed September 9, 2018, http://www.pewresearch.org/fact-tank/2017/11/10 /the-changing-face-of-americas-veteran-population/.

2. Jared Hoppenfeld et al., "Librarians and the Entrepreneurship Bootcamp for Veterans: Helping Disabled Veterans with Business Research," Journal of Business E Finance Librarianship 18, no. 4 (2013): 293-308

3. Sue Samson, "Student Veterans in the Academic Library," College E Undergraduate Libraries 24, no. 1 (2017): 80-89.

4. Sue F. Phelps, "The Veteran Student Experience and the Academic Librarian," The Journal of Academic Librarianship 41, no. 3 (May 2015): 236-240.

5. Virginia Sojdehei, "Boots to Books: Helping College Student Veterans Through Library Outreach and Engagement Programs," CERL News (November 2013): 537-538; Karen Evans, "Serving Those Who Served Us: Resources For Active Duty Soldiers and Veterans" CERL News (September 2012): 470-473.

6. Thomas Atwood et al., "On the Front Lines: Serving Ohio's Best," The Journal of Academic Librarianship 42, no. 2 (March 2016): 172-180.

7. Loriene Roy, "Public Library Services For Veterans: Selected Brief Case Studies," Public Library Quarterly 35, no. 3 (2016): 222-242.

8. Sarah LeMire, "Supporting Our Troops: Library Services and Support for Veterans," Public Services Quarterly 13, no. 3 (2017): 152-167.

9. Chloe Persian Mills, Emily Bounds Paladino, and Jacqueline Courtney Klentzin, "Student Veterans and the Academic Library," Reference Services Review 43, no. 2 (2015): 262-279.

10. Samuel Weingarten, "Student Veterans' Reading Preferences," The Journal of Higher Education 20, no.6 (1949): 299-302, 338.

11. Matthew Rubery, "From Shell Shock to Shellac: The Great War, Blindness, and Britain's Talking Book Library," Twentieth Century History 26, no.1 (2014): 1-25.

12. Kelly D. Chandler, John Dattilo, B. Derrick Taff, and Jeremy Moeller, "Leisure Experiences of Military Couples Postdeployment," Family Relations 67, no. 5 (December 2018): 630-643.

13. Karen K. Melton, Jasmine Townsend, and Camilla J. Hodge, "The Creation of Military Family Leisure Experiences," Journal of Family Theory and Review 10, no. 3 (September 2018): 602-619.

14. Warren D. Price, Neil R. Lundberg, Ramon B. Zabriskle, and Keith W. Barney, "I Tied Flies in My Sleep," Journal of Leisure Research 47, no. 2 (2015): 185-201.

15. "Navy General Library Program," Navy Morale Welfare and Recreation, accessed September 9, 2018, https://www.navymwr .org/programs/libraries.

16. John J. McGrath, The Other End of the Spear: The Tooth-to-Tail Ratio (T3R) in Modern Military Operations (Fort Leavenworth, Kansas: Combat Studies Institute Press, 2007), 67.

17. Ibid., 65 


\section{FEATURE}

18. Genevieve Ames and Carol Cunradi, "Alcohol Use and Preventing Alcohol-Related Problems Among Young Adults in the Military," National Institute on Alcohol Abuse and Alcoholism, accessed September 18, 2018, https://pubs.niaaa.nih.gov/pub lications/arh284/252-257.htm; Rand Corporation, 2015 Health Related Behaviors Survey: Substance Use Among Active-Duty Service Members (Santa Monica, CA: Rand, 2018); Jefferson P. Marquis, Coreen Farris, Kimberly Curry Hall, Kristy N. Kamarck, Nelson Lim, Douglas Shontz, Paul S. Steinberg, Robert Steward,
Thomas E. Trail, Jennier W. Wenger, Anny Wong, and Eunice C. Wong, Improving Oversight and Coordination of Department of Defense Programs that Address Problematic Behaviors Among Military Personnel (Santa Monica, CA: Rand, 2017).

19. Atwood et. al, "On the Front Lines."

20. Integrating the US Military: Race, Gender, and Sexual Orientation since World War II, ed. Douglas Walter Bristol Jr. and Heather Marie Stur (Baltimore, MD: Johns Hopkins, 2017).

\section{APPENDIX A. QUESTIONS ADDED TO THE LIBRARY OF CONGRESS VETERAN INTERVIEW QUESTIONS}

- When you were in the service, did you read for pleasure and if so, what?

- What particular book would you say influenced your life the most?

- Did you use libraries when you were in the service? Why or why not?

- As a veteran, have you used your local library? Why or why not?
- If so, what has the experience been like?

- As a veteran, are there programs or types of books available at the library that you enjoy more than others?

- As a veteran, is there something that you wish you could change about the library that would enhance your enjoyment of it?

\section{APPENDIX B. LIBRARY OF CONGRESS QUESTIONS FOR VETERAN ORAL HISTORY INTERVIEWS}

- Where and when were you born?

- Who are or were your parents and what are or were their occupations?

- Do you have any siblings? Who were they and did they serve in the military?

- What were you doing before you entered the service?

- What branch of the military did you serve in?

- Did you enlist or were you drafted?

- If you enlisted, why did you choose that branch of the service?

- What happened when you departed for training camp and during your early days of training?

- Do you recall your instructors and if so, what were they like?

- Did you receive any specialized training and if so in what?

- How did you adapt to military life, including the physical regimen, barracks, food and social life?

- Where were you stationed?

- If you went abroad, what were some memories of that experience?

- If you were on the front lines, what combat action did you witness?

- If you were not on the front lines, what were your duties?

- If you saw combat, how did you feel when witnessing casualties and destruction?
- What kinds of friendships and camaraderie did you form while serving and with whom?

- How did you stay in touch with family and friends back home?

- What did you do for recreation or when you were offduty?

- Where were you when the war ended?

- How did you return home?

- How were you received by your family and community?

- How did you readjust to civilian life?

- Have you remained in contact with or reunited with fellow veterans and if so, who?

- Are you a member of any veterans' organizations and if so, which?

- What you done since separating from the military?

- How did your military or wartime experiences effect your life?

- What are some life lessons you learned from military service?

- How has your military service impacted your feelings about war and the military in general?

- What message would you like to leave for future generations who will hear this interview?

- Is there anything you feel like we haven't discussed or should be added to this interview and if so, what? 